\title{
TWO NEW SPECIES OF INSECT PHORETIC SICULOBATA (PARALEIUS) (ACARI, ORIBATIDA, SCHELORIBATIDAE) FROM U.S.A. AND TRINIDAD
}

\author{
Sergey G. Ermilov ${ }^{1}$ and Barry M. OCONNOR ${ }^{2}$ \\ ${ }^{1}$ Tyumen State University, Institute of Environmental and Agricultural \\ Biology (X-BIO), Lenina str. 25, 625000 Tyumen, Russia \\ E-mail:ermilovacari@yandex.ru, https://orcid.org/0000-0002-0913-131X \\ ${ }^{2}$ Department of Ecology and Evolutionary Biology (Museum of Zoology) \\ University of Michigan, Ann Arbor, MI, USA; \\ E-mail:bmoc@umich.edu,https://orcid.org/0000-0003-4588-0788
}

Two new species of oribatid mites of the subgenus Siculobata (Paraleius), phoretic on Insecta (Coleoptera and Diptera), are described from the U.S.A. and Trinidad, based on adults. Siculobata (Paraleius) americana sp. n. differs from Siculobata (Paraleius) leontonycha (Berlese, 1910 ) by the presence of monodactylous legs and a slightly modified claw on all pretarsi. Siculobata (Paraleius) trinidadensis sp. $\mathbf{n}$. differs from $S$. (P.) americana $\mathbf{s p .} \mathbf{n}$. by the presence of sublamella, fusiform bothridial seta and a normal claw on pretarsi III, IV, and the absence of pedotectum II. Subgeneric morphological traits and an identification key to known species of Siculobata (Paraleius) are presented.

Key words: new species, Acari, Oribatida, Siculobata mites, systematics, morphology, phoresy, Holarctic and Neotropical regions.

\section{INTRODUCTION}

The oribatid mite subgenus Siculobata (Paraleius) Travé, 1960 (Acari, Oribatida, Scheloribatidae) was proposed by Travé (1960) as independent genus Paraleius Travé, 1960, with Oribella leontonycha Berlese, 1910 as type species. The question of subgeneric or generic status of this taxon has been problematic, and there are many conflicting opinions due to its morphological similarity to several genera/subgenera (reviewed in KNEE 2017). Here, we follow the classification presented by Weigmann (2006), who included Paraleius in Siculobata, but we reject his opinion on the full synonymy of Paraleius with Siculobata and consider the former as a subgenus of the later (see Subías 2015, Ermilov \& Khaustov 2016). We also do not agree with KneE (2017) who synonymized the genus Metaleius Travé, 1960, with Paraleius.

To date, Siculobata (Paraleius) comprises two arboreal species, which are usually associated with insects, often with bark beetles (Curculionidae), inhabiting their galleries and using them as phoresy hosts (e.g., Norton 1980, Ahadiyat \& Akrami 2015, Knee 2017). These species are distributed in the Holarctic and Neotropical regions (SubíAs 2019). Data on distribution, ecology 
and some morphological traits (as for Paraleius) of adults were summarized by KNeE (2017). Data on ontogeny of Siculobata (Paraleius) and its comparison with related genera/subgenera were presented by Ermilov \& Khaustov (2016).

In the course of taxonomic identification of phoretic oribatid mites from the collection of the Museum of Zoology (University of Michigan, USA), we found two new species, belonging to Siculobata (Paraleius). In this paper, we describe and illustrate these new species, update subgeneric morphological traits and give an identification key to known species of the subgenus.

This work is part of our continuing study of oribatid mites phoretic on Insecta (Ermilov 2019, Ermilov \& Frolov 2019a, b), and the oribatid mite fauna of the U.S.A. (ERmilov 2016, 2017a, Ermilov et al. 2019) and Trinidad (Ermilov 2017b, 2018; Ermilov \& Smit 2017).

\section{MATERIAL AND METHODS}

Specimens were mounted in lactic acid on temporary cavity slides for identification, measurement and illustration. Body length was measured in lateral view, from the tip of the rostrum to the posterior edge of the notogaster. Notogastral width refers to the maximum width of the notogaster in dorsal view. Lengths of body setae were measured in lateral aspect. All body measurements are presented in micrometers. Formulas for leg setae are given in parentheses according to the sequence trochanter-femur-genu-tibia-tarsus (famulus included). Formulas for leg solenidia are given in square brackets according to the sequence genu-tibia-tarsus.

Drawings were made with a camera lucida using a Leica transmission light microscope "Leica DM 2500". Microscope images were obtained with an AxioCam ICc3 camera using a Carl Zeiss transmission light microscope "Axio Lab.A1".

Morphological terminology used in this paper follows that of F. GrandjEAn: see TrAvé \& VACHON (1975) for references, NorTON (1977) for leg setal nomenclature, and Norton \& Behan-Pelletier (2009), for overview.

The following abbreviations are used (including text, figures and table): ros = rostrum; lam = lamella; lam = prolamella; slam = sublamella; $A l=$ sublamellar porose area; $k f=$ lateral keel-shaped ridge; $r o, l e, i n, b s, e x=$ rostral, lamellar, interlamellar, bothridial and exobothridial setae, respectively; $e x v=$ alveolar vestige of second exobothridial seta; $b o=$ bothridium; $D=$ dorsophragma; $P=$ pleurophragma; $c, l a, l m, d p, l p, h, p=$ notogastral setae; $S a, S 1, S 2, S 3=$ notogastral sacculi; $i a, i m, i p, i h$, ips = notogastral lyrifissures; gla = opisthonotal gland opening; $a, m, h=$ subcapitular setae; or = adoral seta; $v, l, d, c m, a c m, u l, s u l$, $v t, l t=$ palp setae; $\omega=$ palp and leg solenidion; $c h a, c h b=$ cheliceral setae; $T g=$ Trägårdh's organ; $A h=$ humeral porose area; $I, I I=$ pedotecta I, II, respectively; $1 a, 1 b, 1 c, 2 a, 3 a, 3 b, 3 c$, $4 a, 4 b, 4 c=$ epimeral setae; $d i s=$ discidium; $c p=$ circumpedal carina; $g$, $a g, a n, a d=$ genital aggenital, anal and adanal setae, respectively; iad = adanal lyrifissure; Amar = marginal porose area; $p o=$ preanal organ; $\mathrm{Tr}, \mathrm{Fe}, \mathrm{Ge}, \mathrm{Ti}, \mathrm{Ta}=$ leg trochanter, femur, genu, tibia, tarsus, respectively; cer = cerotegumental excrescence on leg femur; $p a=$ leg porose area; $\sigma, \phi=$ leg solenidia; $\varepsilon=$ leg famulus; $v, e v, b v, l, d, f t, t c, i t, p, u, a, s, p v, p l=$ leg setae. 


\section{SYSTEMATICS}

Family Scheloribatidae

Genus Siculobata Grandjean, 1953

Subgenus Siculobata (Paraleius) Travé, 1960

Type species: Oribella leontonycha Berlese, 1910

\section{MORPHOLOGICAL TRAITS OF SICULOBATA (PARALEIUS)}

Adult. Body size: Small to medium (length less than 550). Integument: Color light brown to brown. Surface without heavily sculpturing and ornamentation. Prodorsum: Rostrum protruding, pointed. Lamella located dorsolaterally on prodorsum, comparatively long and narrow, without cusp. Translamella absent. Prolamella complete, linear. Sublamella and arch-like lateral keel-shaped ridge absent or present. Sublamellar porose area present. Rostral, lamellar, interlamellar and exobothridial setae comparatively long, barbed: ro dorsolaterally on rostrum, le at distal end of lamella, in in interbothridial region, ex lateral to bothridium. Bothridial seta long, clavate or fusiform, barbed. Bothridium cup-shaped. Dorsosejugal porose area not observed. Dorsophragma and pleurophragma present, separate. Notogaster: Anterior notogastral margin convex medially, covering opening of bothridium or not. Posterior notogastral margin rounded. Pteromorph absent. Octotaxic system represented by four pairs of sacculi. Ten pairs of short, setiform notogastral setae. Gnathosoma. Subcapitulum diarthric. Subcapitular setae setiform. Palp with setation 0-2-1-3-9(+ $\omega)$. Solenidion of palptarsus bacilliform, attached to eupathidium. Axillary saccule absent. Chelicera with two setiform setae and elongate triangular Trägårdh's organ. Lateral podosomal and epimeral regions: Pedotecta I and II represented by small lamina, sometimes pedotectum II not developed. Custodium absent. Discidium and circumpedal carina present. Porose area Ah represented by saccule, Am not observed. Epimeral setal formula 3-1-3-3. Epimeral setae short, setiform. Anogenital region: Four pairs of genital, one pair of aggenital, two pairs of anal and three pairs of adanal setae short, setiform. Marginal porose area band-like. Adanal lyrifissure located closely lateral to anal plate. Legs: Monodactylous or heterotridactylous. Claw (central claw, if legs tridactylous) on some or all pretarsi slightly or strongly modified (specifically curved). Porose area present on all femora and on trochanters III, IV. Juvenile instars*. Body surface densely porose, anoadanal region and dorsolateral parts of notogaster folded. Rostral, lamellar, interlamellar and exobothridial setae well-developed. Bothridial seta with distinct head. Formula of gastronotic setae (larva-tritonymph): 11-15-15-15, seta $h_{3}$

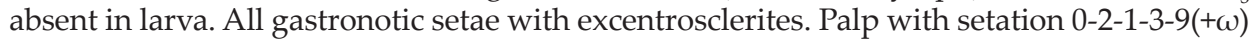
in all instars. Setal formulas for epimeres (larva-tritonymph): 3-1-2, 3-1-2-1, 3-1-2-2, 3-1-3-2. Ontogeny of genital, aggenital, adanal and anal setal formulas (larva-tritonymph): 0-1-2-3, $0-0-1-1,0-0-3-3,0-0-0-2$, respectively. Leg claw of all pretarsi normal (not modified).

\section{Siculobata (Paraleius) americana sp. n. (Figs 1-4)}

Diagnosis. Body size: $348 \times 182-199$. Rostrum pointed. Prolamella and lateral keel-shaped ridge present. Sublamella absent. Rostral, lamellar, inter-

${ }^{*}$ Data based on juvenile instars of one species, Siculobata (Paraleius) leontonycha (see ERMILOV \& KHAUSTOV 2016). 


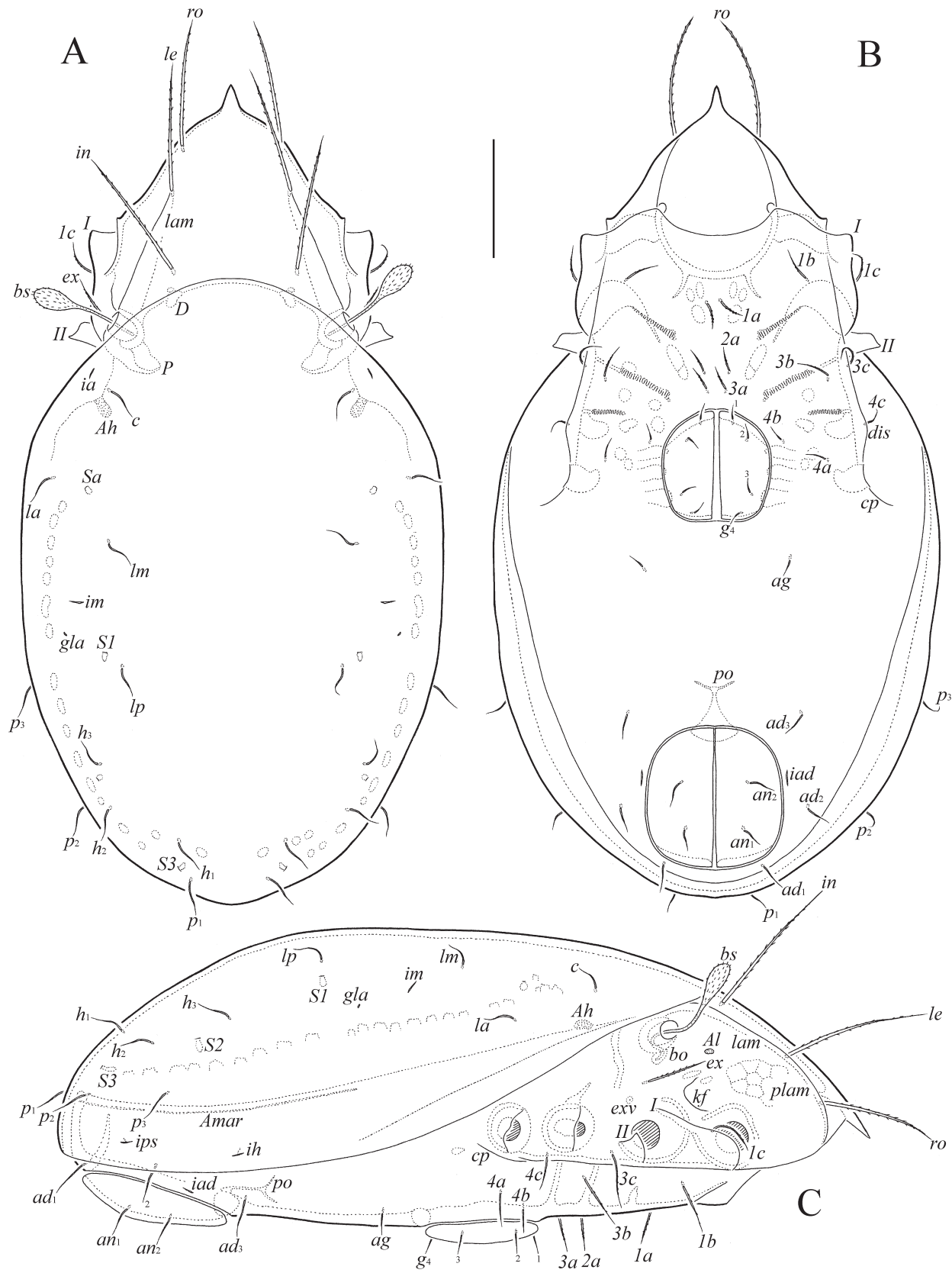

Fig. 1. Siculobata (Paraleius) americana sp. n., adult: $A=$ dorsal view (legs not shown); $B=$ ventral view (gnathosoma and legs not shown); $C=$ lateral view (gnathosoma and legs not shown). Scale bar $50 \mu \mathrm{m}$ 
lamellar and exobothridial setae comparatively long, setiform, barbed. Bothridial seta clavate, barbed. Notogastral seta short, setiform, with attenuate tip, roughened. Epimeral and anogenital setae short, setiform, slightly barbed. Pedotectum II present. Circumpedal carina short. All leg pretarsi with one, slightly modified claw. Femora II-IV with tubercle-like cerotegumental excrescence in ventroanterior part.

Description. Measurements. Body length: 348 (holotype, female), 348, 348 (two paratypes, two females); notogaster width: 182 (holotype), 182, 199 (two paratypes).

Integument. Body color light brown. Surface microfoveolate (visible only under high magnification in dissected specimens).

Prodorsum (Figs 1A, C; 4A-C). Rostrum distinctly protruding, triangular, pointed. Lamella as long as half of prodorsum (measured in lateral view). Prolamella complete, thin. Sublamella absent. Sublamellar porose area rounded $(4)$ or oval $(4 \times 2)$. Lateral keel-shaped ridge developed. Rostral (57-61), lamellar (65-69), interlamellar (73-77) and exobothridial (36-41) setae setiform, barbed. Bothridial seta (45-53) clavate, with long, roughened stalk and shorter, barbed, clearly rounded apically head. Dorsosejugal porose area not observed.

Notogaster (Figs 1A, C; 2A). Anterior notogastral margin distinctly convex medially. Ten pairs of notogastral setae (18-24) setiform, with attenuate tip, roughened. Four pairs of sacculi with small opening and slightly elongate chamber. Distance S1-S1 little shorter than S2-S2. Notogastral lyrifissure ( $i a, i m$, ip, ih, ips), opisthonotal gland opening and circumgastric sigillar band distinct. Circumgastric scissure present, no often slightly visible.

Gnathosoma (Figs 2B-D). Subcapitulum longer than wide (69-73 $\times$ 53-61). Subcapitular $(a, 14-16 ; m, 14-16 ; h, 24)$ and adoral $(6)$ setae setiform, barbed. Palp (length 45-53) with

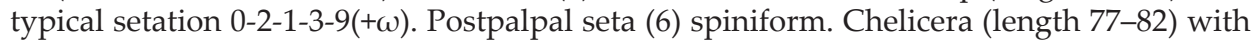
two setiform, barbed setae (cha, 24-28; chb, 14-18). Trägårdh's organ elongate triangular.

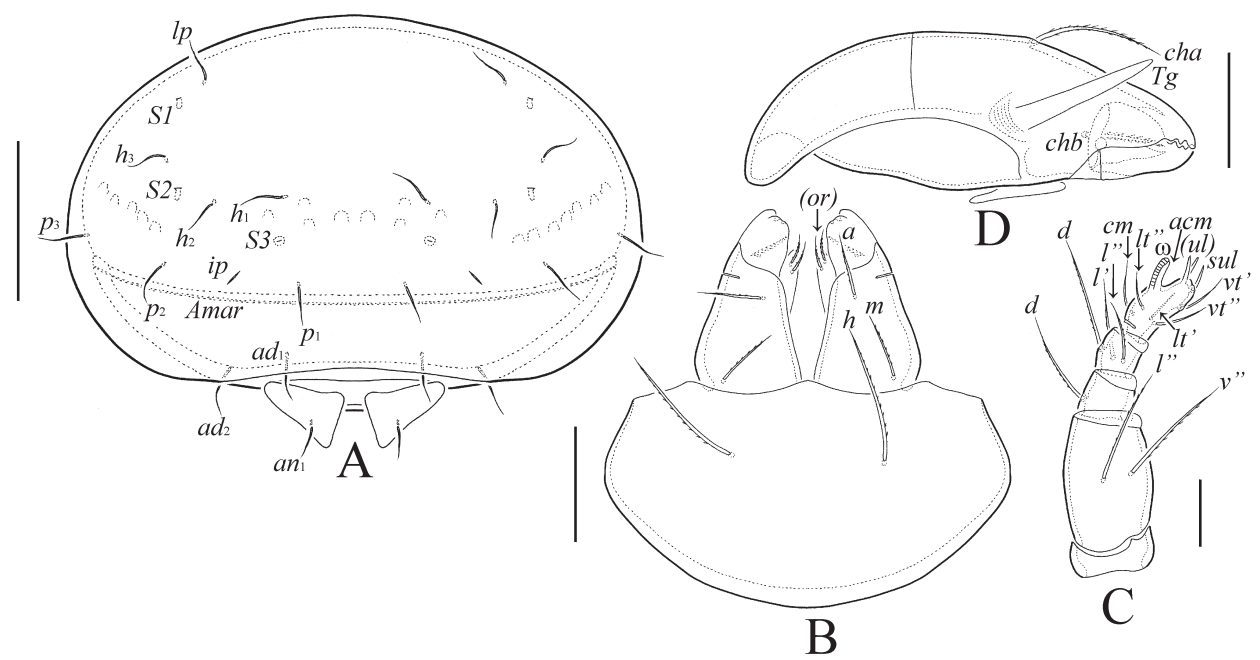

Fig. 2. Siculobata (Paraleius) americana sp. n., adult: $\mathrm{A}=$ posterior view; $\mathrm{B}=$ subcapitulum, ventral view; $C=$ palp, right, antiaxial view; $D=$ chelicera, left, paraxial view. Scale bar 50 $\mu \mathrm{m}(\mathrm{A}), 20 \mu \mathrm{m}(\mathrm{B}, \mathrm{D}), 10 \mu \mathrm{m}(\mathrm{C})$ 


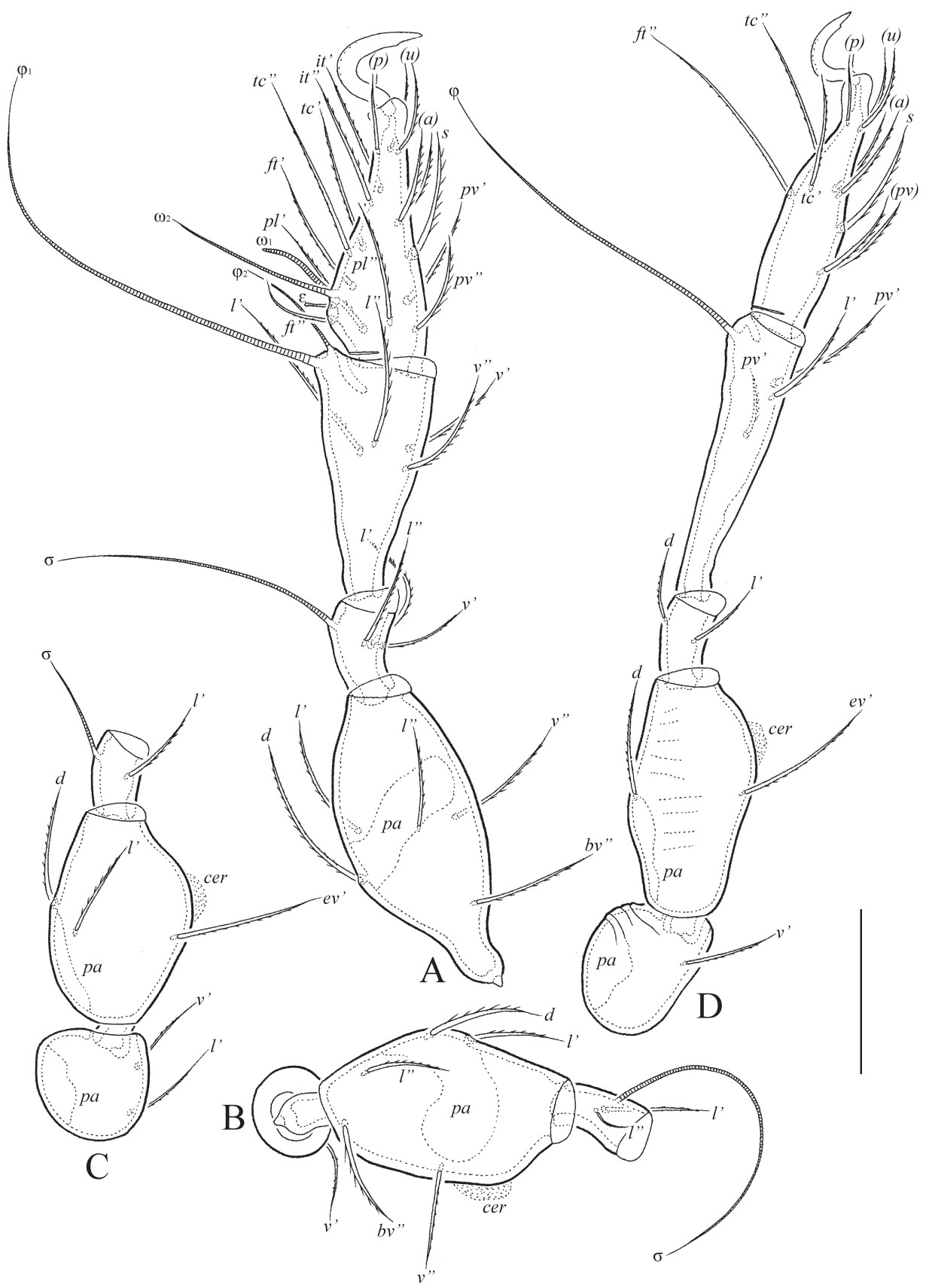

Fig. 3. Siculobata (Paraleius) americana sp. n., adult: A = leg I, without trochanter, right, antiaxial view; $\mathrm{B}=$ trochanter, femur and genu of leg II, right, antiaxial view; $\mathrm{C}=$ trochanter, femur and genu of leg III, left, antiaxial view; D = leg IV, left, antiaxial view. Scale bar $20 \mu \mathrm{m}$ 
Epimeral and lateral podosomal regions (Figs 1B, C; 4D). With typical epimeral setal formula: 3-1-3-3. Epimeral setae (1b, 1c, 3b, 3c, 24-32; 1a, 2a, 3a, 4a, 4c, 16-20; 4b, 10-12) setiform, slightly barbed, $1 a, 2 a, 3 a$ thicker and more barbed. Pedotecta I and II represented by small lamina, I rounded in lateral view, II trapezoidal in ventral view, with one elongated tooth-like top. Discidium slightly developed, rounded. Humeral porose area $A h$ represented by saccule, $A m$ absent. Circumpedal carina short, directed to acetabulum IV.

Anogenital region (Figs 1B, C; 2A). Four pairs of genital (8-10), one pair of aggenital (10-12), two pairs of anal (14-18) and three pairs of adanal (20-24) setae setiform, thin, roughened. Adanal lyrifissure distinct. Adanal seta $a d_{1}$ posterior, $a d_{2}$ lateral, $a d_{3}$ anterior to anal aperture. Marginal porose area poorly visible, complete, band-like, very thin. Preanal organ of typical, goblet-like form. Ovipositor elongated $(134 \times 32)$, blade $(61)$ shorter than length of distal section (beyond middle fold; 73). Each of the three blades with four smooth setae, $\psi_{1} \approx \tau_{1}$ (32) setiform, $\psi_{2} \approx \tau_{\mathrm{a}} \approx \tau_{\mathrm{b}} \approx \tau_{\mathrm{c}}$ (14) thorn-like. Six coronal setae (2) spiniform.
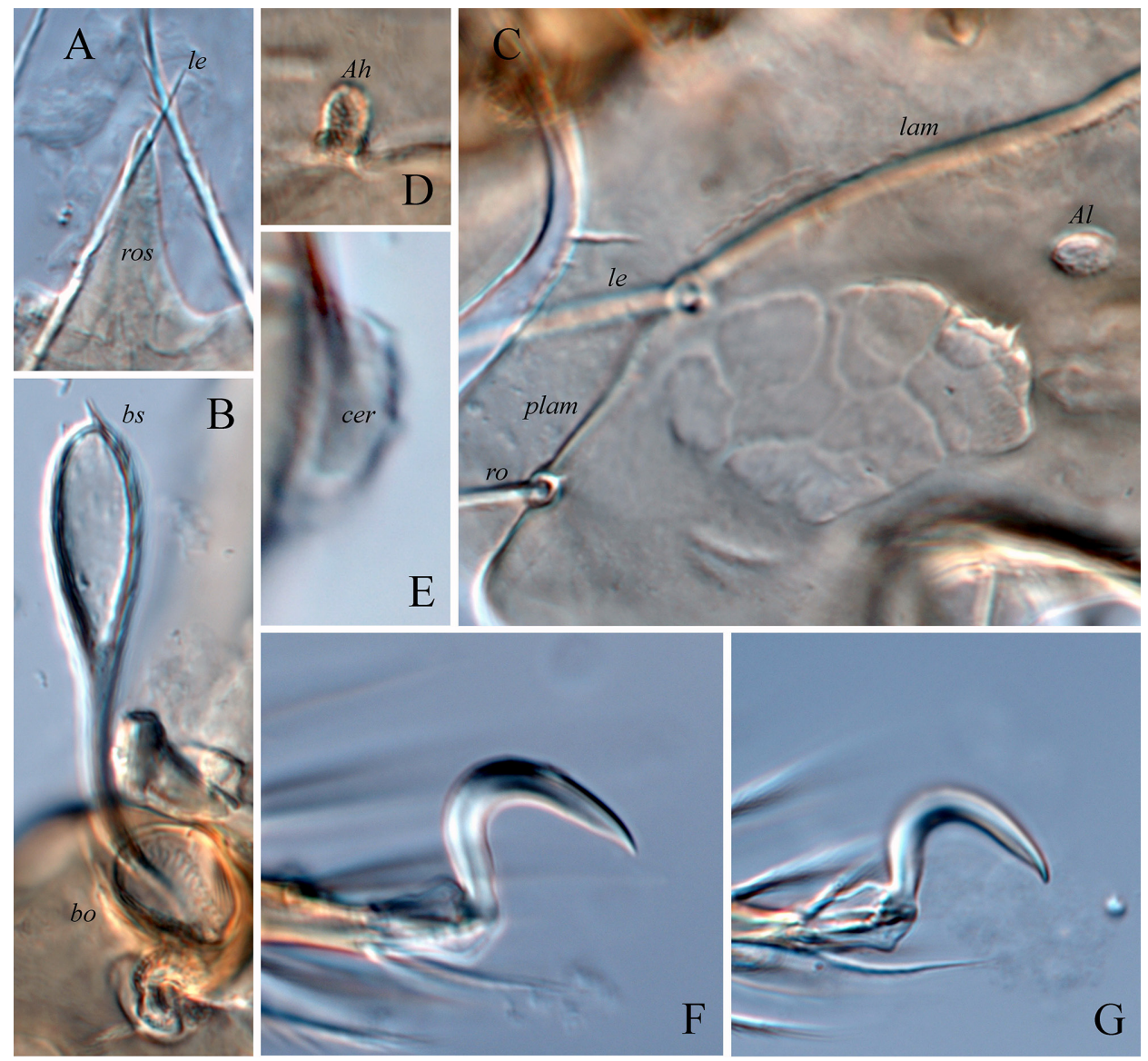

Fig. 4. Siculobata (Paraleius) americana sp. n., dissected adult, microscope images: A = rostrum; $\mathrm{B}=$ bothridial seta $\mathrm{C}=$ part of lateral side of prodorsum; $\mathrm{D}=$ humeral saccule $A h ; \mathrm{E}=$ cerotegumental excrescence in ventroanterior part of leg femur II; F = leg claw II; G = leg claw III 
Table 1. Leg setation and solenidia of adult Siculobata (Paraleius) americana sp. n. and S. (P.) trinidadensis sp. $\mathbf{n}$.

\begin{tabular}{lccccc}
\hline Leg & Tr & Fe & Ge & Ti & Ta \\
\hline I & $v^{\prime}$ & $d,(l), b v^{\prime \prime}, v^{\prime \prime}$ & $(l), v^{\prime}, \sigma$ & $(l),(v), \phi_{1^{\prime}}$ & $(f t),(t c),(i t),(p),(u),(a), s,(p v),(p l), \varepsilon$, \\
& & & $\phi_{2}$ & $\omega_{1^{\prime}} \omega_{2}$ \\
II & $v^{\prime}$ & $d,(l), b v^{\prime \prime}, v^{\prime \prime}$ & $(l), \sigma$ & $(l),(v), \phi$ & $(f t),(t c),(i t),(p),(u),(a), s,(p v), \omega_{1}, \omega_{2}$ \\
III & $l^{\prime}, v^{\prime}$ & $d, l^{\prime}, e v^{\prime}$ & $l^{\prime}, \sigma$ & $l^{\prime},(v), \phi$ & $(f t),(t c),(i t),(p),(u),(a), s,(p v)$ \\
IV & $v^{\prime}$ & $d, e v^{\prime}$ & $d, l^{\prime}$ & $l^{\prime},(v), \phi$ & $f t^{\prime \prime},(t c),(p),(u),(a), s,(p v)$ \\
\hline
\end{tabular}

Roman letters refer to normal setae, Greek letters to solenidia (except $\varepsilon=$ famulus). Single prime (') marks setae on the anterior and double prime (") setae on the posterior side of a given leg segment. Parentheses refer to a pair of setae.

Leg (Figs 3A-D; 4E-G). Monodactylous. Claw slightly modified, forming slight right angle (not evenly, semi-oval, curved), sparsely barbed on dorsal side, with unclear tubercle ventrodistally. Claw of pretarsi I, II slightly thicker than claw of pretarsi III, IV. Dorsoparaxial porose area on all femora and on trochanters III, IV present. Ventroproximal porose area on all tarsi and ventrodistal porose area on all tibiae not observed. Femora II-IV with tubercle-like cerotegumental excrescence in ventroanterior part. Formulas of leg setation and solenidia: I (1-5-3-4-18) [1-2-2], II (1-5-2-4-15) [1-1-2], III (2-3-1-3-15) [1-1-0], IV (1-2-2-312) [0-1-0]; homology of setae and solenidia indicated in Table 1. Famulus of tarsus I short, straight, slightly swollen distally, located between solenidion $\omega_{2}$ and seta $f t^{\prime \prime}$. Solenidion $\omega_{1}$ on tarsus I, $\omega_{1}$ and $\omega_{2}$ on tarsus II bacilliform, other solenidia setiform.

Material examined. Holotype (female) and two paratype females: USA, Michigan, Cheboygan Co., University of Michigan Biological Station, $45^{\circ} 33^{\prime} 42^{\prime \prime} \mathrm{N}, 84^{\circ} 40^{\prime \prime} 03^{\prime \prime} \mathrm{W}$, active phoresy on Osmoderma eremicola (Coleoptera, Scarabaeidae), 2 August 1982 (B.M. OConnor) (BMOC 82-0802-017).

Type deposition. The holotype and one paratype are deposited in the collection of the University of Michigan Museum of Zoology, Ann Arbor, MI, USA; one paratype is deposited in the collection of the Tyumen State University Museum of Zoology, Tyumen, Russia. All specimens are stored in ethanol with a drop of glycerol.

Etymology. The specific name americana refers to the country of origin, U.S.A.

Remarks. The new species is morphologically similar to Siculobata (Paraleius) leontonycha (Berlese, 1910) in having clavate bothridial seta, but differs from the latter by the presence of one claw on all leg pretarsi (versus three claws) and slightly modified (slightly curved) claw on all leg pretarsi (versus central claw strongly modified, abruptly curved).

Norton (1973) listed mites phoretic on O. eremicola, and noted the presence of the oribatid mite, Mesoplophora pulchra Sellnick, 1928 (located on venter near coxae), on two of fourteen museum specimens of this beetle he examined. He did not mention the species described here. Osmoderma eremicola larvae inhabit galleries in decaying wood (HoffmAN 1939). 


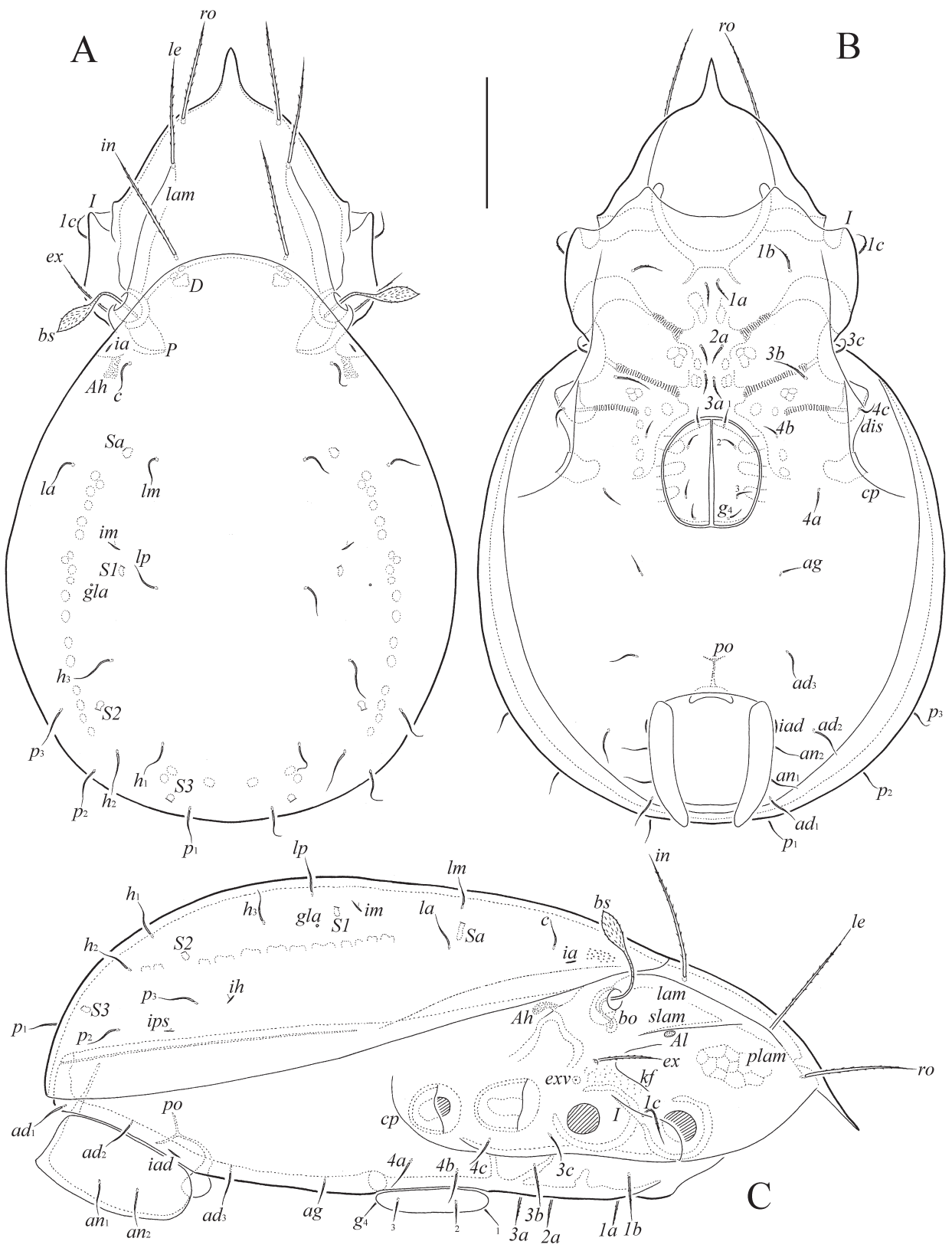

Fig. 5. Siculobata (Paraleius) trinidadensis sp. n., adult: $\mathrm{A}=$ dorsal view (legs not shown); $\mathrm{B}=$ ventral view (gnathosoma and legs not shown); $\mathrm{C}=$ lateral view (gnathosoma and legs not shown). Scale bar $50 \mu \mathrm{m}$ 


\section{Siculobata (Paraleius) trinidadensis sp. $\mathrm{n}$.}

(Figs 5-8)

Diagnosis. Body size: 298-315 × 166-182 . Rostrum pointed. Prolamella, sublamella and lateral keel-shaped ridge present. Rostral, lamellar, interlamellar and exobothridial setae comparatively long, setiform, barbed. Bothridial seta fusiform, barbed. Notogastral seta short, setiform, with attenuate tip, roughened. Epimeral and anogenital setae short, setiform, slightly barbed. Pedotectum II absent. Circumpedal carina of medium size. Leg pretarsi I, II with one modified (specifically curved) claw, leg pretarsi III, IV normal, not modified.

Description. Measurements. Body length: 298 (holotype, female), 298, 315 (two paratypes, one male and one female); notogaster width: 166 (holotype), 166, 182 (two paratypes).

Integument. Body color light brown. Surface microfoveolate (visible only under high magnification in dissected specimens). Humeral region of notogaster slightly microtuberculate. Region between lamella and sublamella slightly striate.

Prodorsum (Figs 5A, C; 8A-C). Rostrum distinctly protruding, triangular, pointed. Lamella as long as half of prodorsum (measured in lateral view). Prolamella complete, thin, often poorly visible in mediodistal part. Sublamella present. Sublamellar porose area rounded $(4)$ or oval $(4 \times 2)$. Lateral keel-shaped ridge developed. Rostral (45-49), lamellar (53-61), interlamellar (65-73) and exobothridial (28-36) setae setiform, barbed. Bothridial seta (45-49) fusiform, with long, roughened stalk and shorter, barbed, clearly pointed apically head. Dorsosejugal porose area not observed.

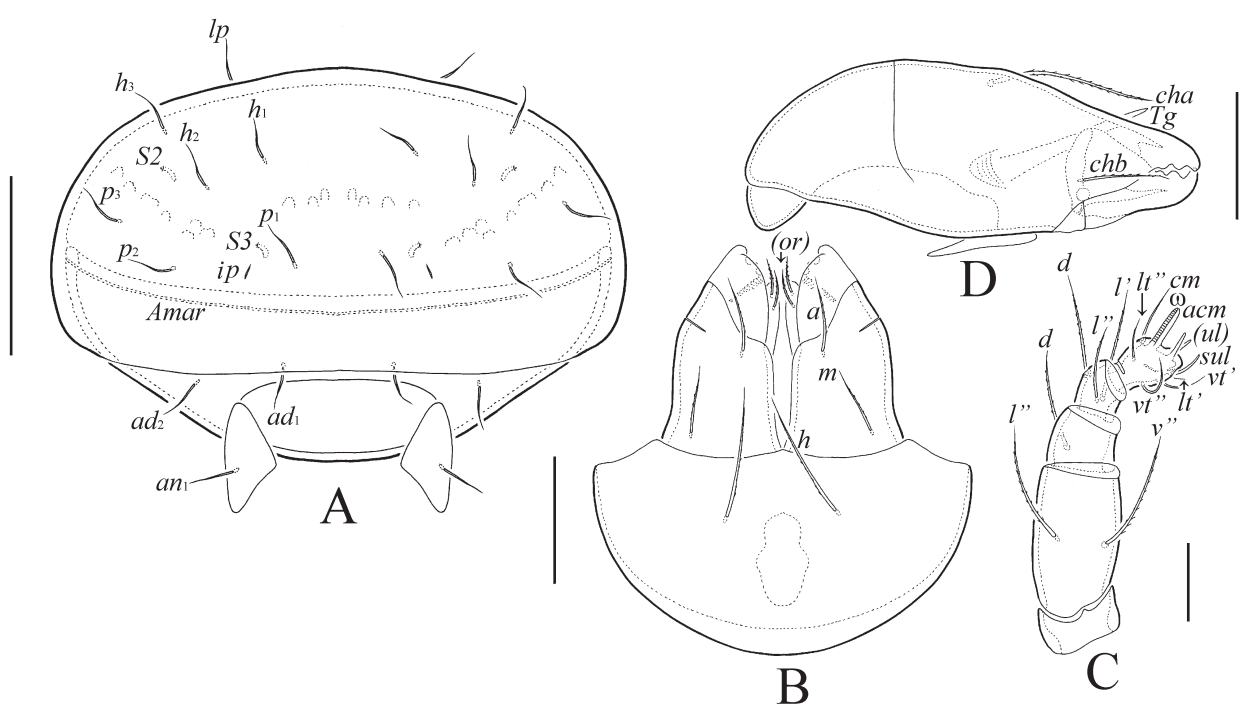

Fig. 6. Siculobata (Paraleius) trinidadensis sp. $\mathbf{n}$. , adult: $\mathrm{A}=$ posterior view; $\mathrm{B}=$ subcapitulum, ventral view; $C=$ palp, right, antiaxial view; $D=$ chelicera, right, antiaxial view. Scale bar $50 \mu \mathrm{m}(\mathrm{A}), 20 \mu \mathrm{m}(\mathrm{B}, \mathrm{D}), 10 \mu \mathrm{m}(\mathrm{C})$ 
Notogaster (Figs 5A, C; 6A). Anterior notogastral margin distinctly convex medially. Ten pairs of notogastral setae (14-16) setiform, with attenuate tip, roughened. Four pairs of sacculi with small opening and slightly elongate chamber. Distance S1-S1 little shorter than S2-S2. Notogastral lyrifissure (ia, im, ip, ih, ips), opisthonotal gland opening and circumgastric sigillar band distinct. Circumgastric scissure present, no often slightly visible.

Gnathosoma (Figs 6B-D). Subcapitulum longer than wide (65-69 × 53-57). Subcapitular $(a, 12-14 ; m, 10-12 ; h, 16-20)$ and adoral (6) setae setiform, barbed. Palp (length 45-49)

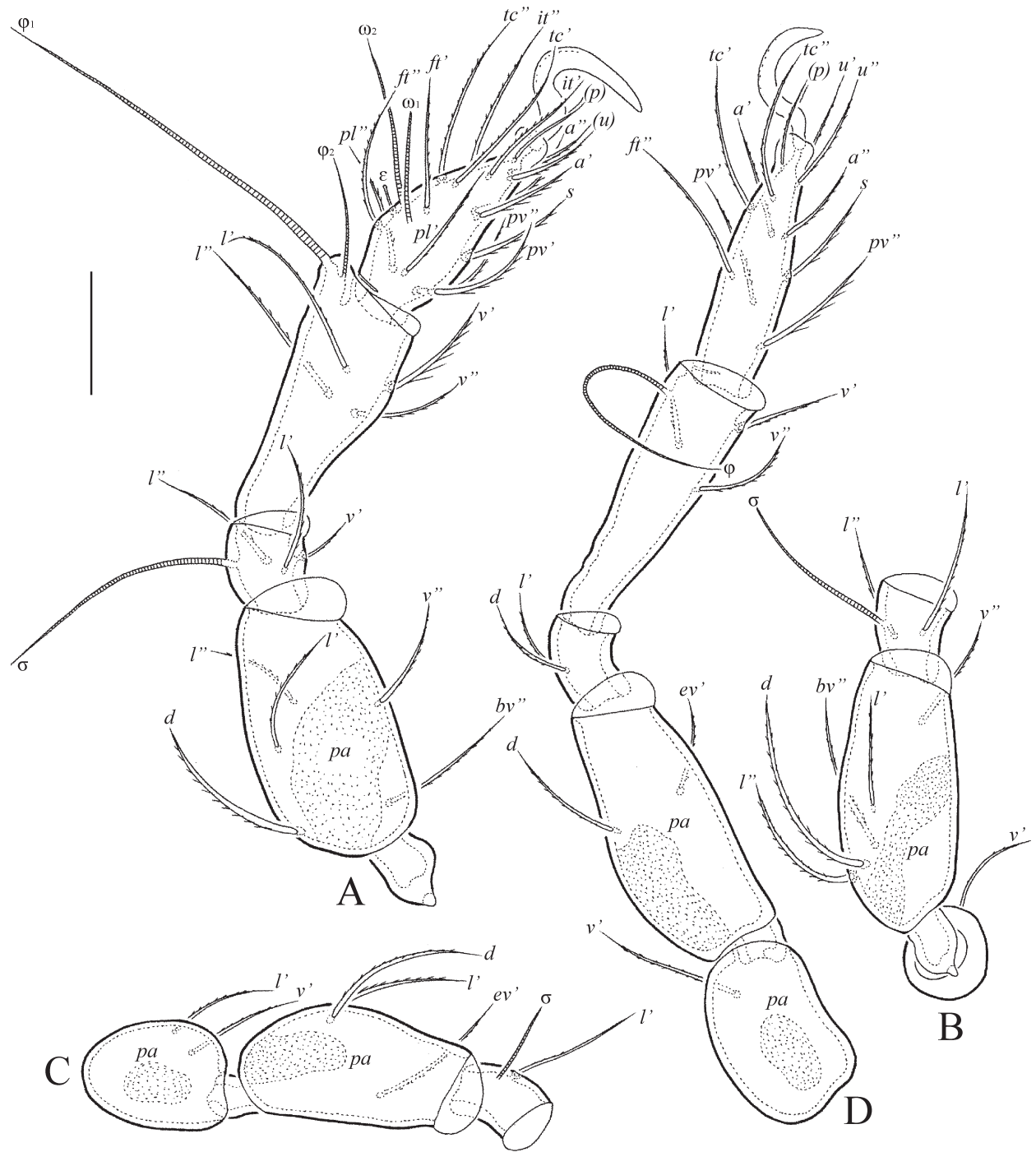

Fig. 7. Siculobata (Paraleius) trinidadensis sp. n., adult: A = leg I, without trochanter, left, paraxial view; $\mathrm{B}=$ trochanter, femur and genu of leg II, left, paraxial view; $\mathrm{C}=$ trochanter, femur and genu of leg III, right, paraxial view; D = leg IV, right, paraxial view. Scale bar $20 \mu \mathrm{m}$ 


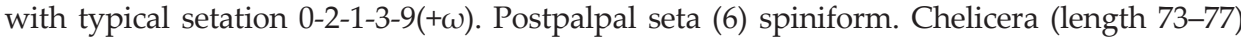
with two setiform, barbed setae (cha, 24-28; chb, 14-16). Trägårdh's organ elongate triangular.

Epimeral and lateral podosomal regions (Figs 5B, C; 8D). With typical epimeral setal formula: 3-1-3-3. Epimeral setae (1b, 1c, 3b, 18-20; 1a, 2a, 3a, 3c, 4a, 4b, 4c, 14-16) setiform, slightly barbed, $1 a, 2 a, 3 a$ thicker and more barbed. Pedotectum I represented by small lamina, pedotectum II not developed. Discidium distinct, rounded. Humeral porose area Ah represented by saccule, $A m$ absent. Circumpedal carina of medium size, directed to discidium.

Anogenital region (Figs 5B, C; 6A). Four pairs of genital (8), one pair of aggenital (8-10), two pairs of anal (14-16) and three pairs of adanal (14-16) setae setiform, thin, roughened. Adanal lyrifissure distinct. Adanal seta $a d_{1}$ posterior, $a d_{2}$ lateral, $a d_{3}$ anterior to
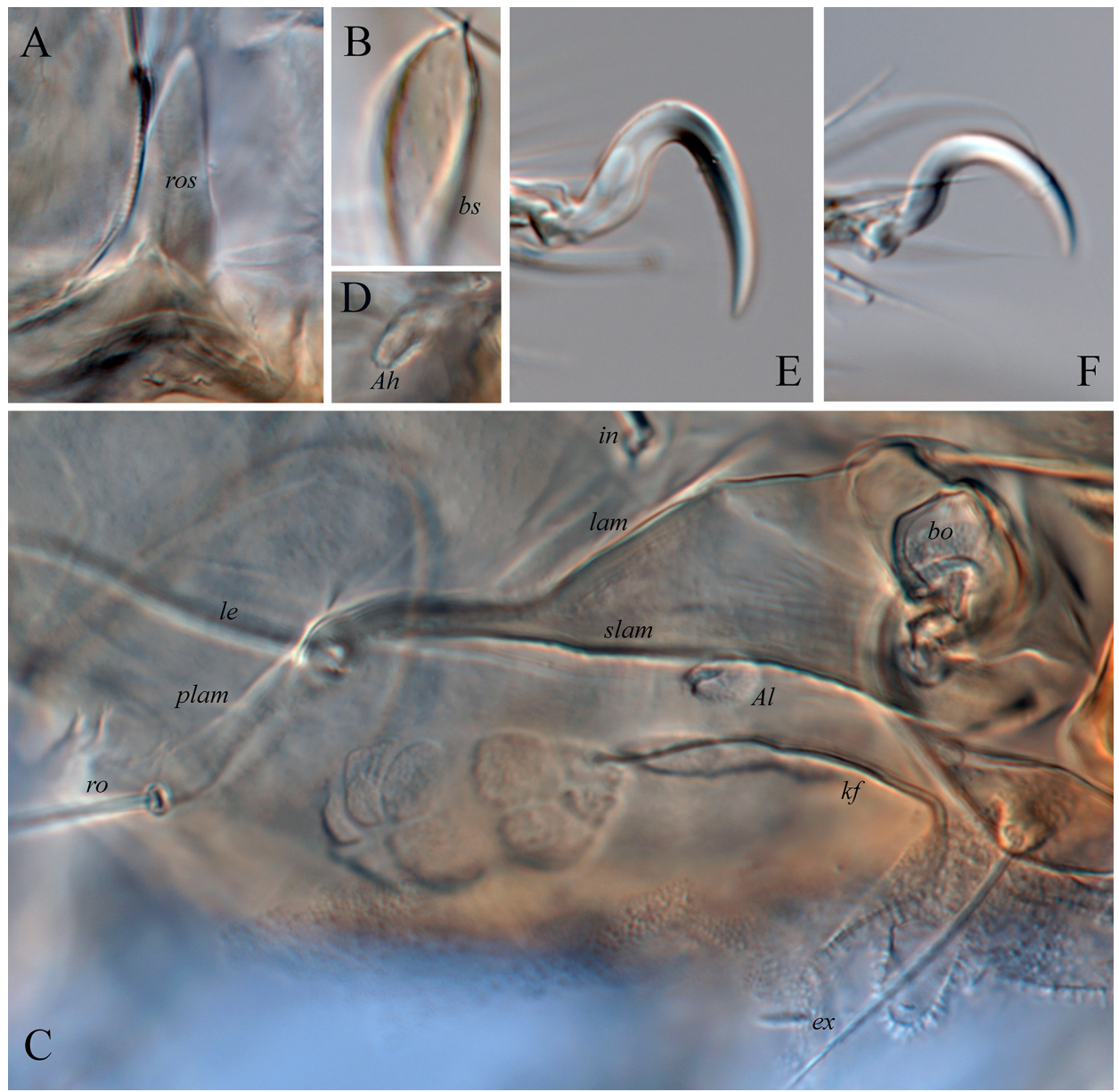

Fig. 8. Siculobata (Paraleius) trinidadensis sp. n., dissected adult, microscope images: $\mathrm{A}=$ rostrum; $\mathrm{B}=$ bothridial head; $\mathrm{C}=$ part of lateral side of prodorsum; $\mathrm{D}=$ humeral saccule $A h$; $\mathrm{E}=$ leg claw II; F = leg claw III 
anal aperture. Marginal porose area poorly visible, complete, band-like, very thin. Preanal organ of typical, goblet-like form. Ovipositor elongated $(98 \times 28)$, blade $(45)$ shorter than length of distal section (beyond middle fold; 53). Each of the three blades with four smooth setae, $\psi_{1} \approx \tau_{1}$ (32) setiform, $\psi_{2} \approx \tau_{\mathrm{a}} \approx \tau_{\mathrm{b}} \approx \tau_{\mathrm{c}}$ (14) thorn-like. Six coronal setae (2) spiniform.

Leg (Figs 7A-D; 8E, F). Monodactylous. Claw of pretarsi I, II modified, specifically curved, sparsely barbed on dorsal side. Claw of pretarsi III, IV evenly, semi-oval, curved (not modified), sparsely barbed on dorsal side. Dorsoparaxial porose area on all femora and on trochanters III, IV present. Ventroproximal porose area on all tarsi and ventrodistal porose area on all tibiae not observed. Formulas of leg setation and solenidia: I (1-5-3-4-18) [1-2-2], II (1-5-2-4-15) [1-1-2], III (2-3-1-3-15) [1-1-0], IV (1-2-2-3-12) [0-1-0]; homology of setae and solenidia indicated in Table 1. Famulus of tarsus I short, straight, slightly swollen distally, located between solenidion $\omega_{2}$ and seta $f t$ ". Solenidion $\omega_{1}$ on tarsus I, $\omega_{1}$ and $\omega_{2}$ on tarsus II bacilliform, other solenidia setiform.

Material examined. Holotype (female) and two paratypes (one male and one female): Trinidad, no further locality, active phoresy on a specimen of Pantophthalmus heydeni (Diptera, Pantophthalmidae), 16 June 1956 (collector not known) (BMOC 75-0530-001).

Type deposition. The holotype and one paratype are deposited in the collection of the University of Michigan Museum of Zoology, Ann Arbor, MI, USA; one paratype is deposited in the collection of the Tyumen State University Museum of Zoology, Tyumen, Russia. All specimens are stored in ethanol with a drop of glycerol.

Etymology. The specific name trinidadensis refers to the place of origin, Trinidad.

Remarks. The new species is morphologically similar to Siculobata (Paraleius) americana sp. $\mathrm{n}$. in having one claw on all leg pretarsi and short notogastral setae with attenuate tip, but differs from the latter by the presence of sublamella (versus absent), pointed apically bothridial head (versus rounded) and normal claw (not modified) on leg pretarsi III, IV (versus modified), and the absence of pedotectum II (versus present).

Norton (1980) noted this species as "Metaleius sp. D" (located mostly laterally and ventrally on thorax of P. heydeni) based on specimens from the same host insect specimen provided to him by the junior author.

Like other insects with which $S$. (Paraleius) species are associated, larvae of the dipteran family Pantophthalmidae inhabit galleries in wood (Austen 1923).

\section{Key to known species of Siculobata (Paraleius)}

1. All leg pretarsi with three claws; body size: $431-531 \times 232-315$. Distribution: Holarctic region, Mexico. S. (P.) leontonycha (Berlese, 1910) (see also Travé 1960, Wunderle et al. 1990, MahunKa 1996, including personal data of the first author).

- $\quad$ All leg pretarsi with one claw 
2. Claw on all leg pretarsi strongly modified and abruptly curved; bothridial seta distinctly elongate fusiform; body size: 432-464 × 423-440. Distribution: Canada.

S. (P.) leahae (Knee, 2017)

- Claw on all or some leg pretarsi slightly modified and slightly curved; bothridial seta clavate or normally (not distinctly elongate) fusiform

3. Sublamella present; bothridial head pointed apically; pedotectum II not developed; claw on leg pretarsi III, IV not modified; body size: 298-315 × 166-182. Distribution: Trinidad. S. (P.) trinidadensis sp. $\mathbf{n}$.

- Sublamella absent; bothridial head rounded apically; pedotectum II developed; claw on leg pretarsi III, IV slightly modified; body size: $348 \times$ 182-199. Distribution: U.S.A.

S. (P.) americana sp. $\mathbf{n}$.

Acknowledgements - The authors thank Prof. Dr. Roy A. Norton (State University of New York, Syracuse, USA) for many years of cooperation and collaboration, including this research; and two anonymous reviewers for valuable comments.

\section{REFERENCES}

Ahadiyat, A. \& Akrami, M. A. (2015): Oribatid mites (Acari: Oribatida) associated with bark beetles (Coleoptera: Curculionidae: Scolytinae) in Iran, with a review on Paraleius leontonychus (Berlese) and a list of bark beetles in association with this species. - Persian Journal of Acarology 4: 355-371. http://dx.doi.org/10.22073/pja.v4i4.14730

Austen, E. E. (1923): A revision of the family Pantophthalmidae (Diptera), with descriptions of a new species and a new genus. - Proceedings of the Zoological Society of London 1923: 551-598. https://doi.org/10.1111/j.1096-3642.1923.tb02198.x

Berlese, A. (1910): Brevi diagnosi di generi e species nuovi di Acari. Redia 6: 346-388.

Ermilov, S. G. \& Khaustov, A. A. (2016): Juvenile instars of Siculobata (Paraleius) leontonycha (Acari, Oribatida, Scheloribatidae). - Systematic and Applied Acarology 21: 1379-1391. https://doi.org/10.11158/saa.21.10.8

Grandjean, F. (1953): Sur les genres "Hemileius" Berl. et "Siculobata" n.g. (Acariens, Oribates). - Mémoires du Muséum National d'Histoire Naturelle 6: 117-138.

Hoffman, C. H. (1939): The biology and taxonomy of the Nearctic species of Osmoderma (Coleoptera, Scarabaeidae). - Annals of the Entomological Society of America 32: 510525. https://doi.org/10.1093/aesa/32.3.510

KneE, W. (2017): A new Paraleius species (Acari, Oribatida, Scheloribatidae) associated with bark beetles (Curculionidae, Scolytinae) in Canada. - ZooKeys 667: 51-65. https://doi.org/10.3897/zookeys.667.12104

Mahunka, S. (1996): Oribatids of the Bükk National Park (Acari: Oribatida). Pp. 491-532. In: Mahunka, S. (ed.): The fauna of the Bükk National Park. - Hungarian Natural History Museum, Budapest.

Norton, R. A. (1973): Phoretic mites associated with the hermit flower beetle, Osmoderma eremicola Knoch (Coleoptera: Scarabaeidae). - American Midland Naturalist 90: 447449. https://doi.org/10.2307/2424466 
Norton, R. A. (1977): A review of F. Grandjean's system of leg chaetotaxy in the Oribatei (Acari) and its application to the family Damaeidae. Pp. 33-61. In: Dindal, D. L. (ed.): Biology of oribatid mites. SUNY College of Environmental Science and Forestry, Syracuse.

Norton, R. A. (1977): A review of F. Grandjean's system of leg chaetotaxy in the Oribatei (Acari) and its application to the family Damaeidae. Pp. 33-61. In: Dindal, D. L. (ed.): Biology of oribatid mites. SUNY College of Environmental Science and Forestry, Syracuse.

Norton, R. A. \& Behan-Pelletier, V. M. (2009): Suborder Oribatida. Chapter 15. Pp. 430564. In: Krantz, G. W. \& Walter, D. E. (eds): A manual of Acarology. Texas Tech University Press, Lubbock.

SubíAs, L. S. (2015): Listado sistemático, sinonímico y biogeográfico de los ácaros oribátidos (Acariformes: Oribatida) del mundo (excepto fósiles). Online version accessed in March 2015, 587 pp.

Subías, L. S. (2019): Listado sistemático, sinonímico y biogeográfico de los ácaros oribátidos (Acariformes: Oribatida) del mundo (excepto fósiles). Online version accessed in March 2019, 536 pp.; http://bba.bioucm.es/cont/docs/RO_1.pdf

Travé, J. (1960): Contribution a l'étude de la faune de la Massane (3e note), Oribates (Acariens). 2e partie (I). - Vie et Milieu 11: 209-232.

Travé, J. \& VAchon, M. (1975): François Grandjean. 1882-1975 (Notice biographique et bibliographique). - Acarologia 17: 1-19.

Weigmann, G. (2006): Hornmilben (Oribatida). - Die Tierwelt Deutschlands. Teil 76. Keltern, Goecke and Evers, 520 p.

Wunderle, I., Beck, L. \& WoAs, S. (1990): Ein Beitrag zur Taxonomie und Ökologie der Oribatulidae und Scheloribatidae (Acari, Oribatei) in Südwestdeutschland. - Andrias 7: 15-60.

Received February 3, 2020, accepted August 6, 2020, published November 13, 2020 


\section{The oribatid species described by Berlese (Acari)}

by MAHUNKA, S. and L. MAHUNKA-PAPP

The authors had the opportunity for years to study the Oribatid species described by Berlese currently deposited in the Istituto Sperimentale per la Zoologia Agraria at Florence. The results of this series of studies are summarized in this volume.

The volume begins with an essay-like Introduction heavily relying on subjective opinions discussing the general questions of Oribatology. The following section lists Berlese's species placed in the modern system helping the specialists with morphological notes and many drawings; here also the condition of the specimens is discussed and lectotypes are designated.

The third, large section is the catalogue proper, wherein all the species are listed in the systematic order together with their combination and synonymic names. Here one may find all the literature data, usually missing from ordinary works, with reference to Description and Taxonomy, Distribution, with special emphasis on Catalogues whose references are partly unreliable. Where it was deemed necessary further information are added under the heading of Remarks. The volume closes with a very detailed list of literature.

ISBN 9637093273

325 pages with several figures. Soft bound.

Hungarian Natural History Museum, Budapest, 1995

Price: 40 US dollars excluding package and postage

Order should be sent

to the Hungarian Natural History Museum, Library

Baross u. 13, Budapest, H-1088 Hungary

Fax: (36-1) 3171669 